Revista de Metalurgia

April-June 2018, 54 (2), e116

ISSN-L: 0034-8570

https://doi.org/10.3989/revmetalm.116

\title{
The removal of toxic metals from liquid effluents by ion exchange resins. Part VI: Manganese(II)/H+/Lewatit K2621
}

\author{
Francisco J. Alguacil ${ }^{\varpi}$ \\ Centro Nacional de Investigaciones Metalúrgicas (CENIM, CSIC), Avda. Gregorio del Amo 8, 28040 Madrid, España \\ Corresponding author: fjalgua@cenim.csic.es
}

Submitted: 17 May 2017; Accepted: 13 July 2017; Available On-line: 10 May 2018

\begin{abstract}
In this sixth part of the series, Manganese(II) was removed from aqueous solutions by the cationic exchange resin Lewatit K2621. The investigation was performed under various experimental conditions such as the stirring speed associated with the system, aqueous $\mathrm{pH}$, temperature, resin dosage and the ionic strength of the solution. The performance of the resin against the loading of metals from metal-binary solutions as well as the removal of Manganese(II) from the solutions using multiwalled carbon nanotubes and functionalized (carboxylic groups) multiwalled carbon nanotubes, were also investigated. Experimental results fit well with the pseudo-first kinetic order model, whereas fit of the data show that at $20^{\circ} \mathrm{C}$ the process responded well to the diffusion controlled model, and that at $60^{\circ} \mathrm{C}$, the system is controlled by the moving boundary model. Adsorption data is better related to the Freundlich isotherm. Elution of the Manganese(II) loaded onto the resin was investigated using acidic $\left(\mathrm{H}_{2} \mathrm{SO}_{4}\right.$ or $\left.\mathrm{HCl}\right)$ solutions.
\end{abstract}

KEYWORDS: Lewatit K2621; Liquid effluents; Manganese(II); Multiwalled carbon nanotubes; Removal

Citation/Citar como: Alguacil, F.J. (2018). "The removal of toxic metals from liquid effluents by ion exchange resins. Part VI: Manganese(II)/HLewatit K2621”. Rev. Metal. 54(2): e116. https://doi.org/10.3989/revmetalm.116

RESUMEN: Eliminación de metales tóxicos presentes en efluentes líquidos mediante resinas de cambio iónico. Parte VI: Manganeso(II) )/H+/Lewatit K2621. En esta sexta parte de la serie de trabajos sobre la eliminación de metales tóxicos de disoluciones acuosas, se presentan datos sobre el sistema manganeso(II)-Lewatit K2621. La investigación se ha llevado a cabo empleando diferentes condiciones experimentales como son la velocidad de agitación asociada al sistema, el pH del medio acuoso, la temperatura, la adicción de distintas cantidades de resina a la disolución acuosa que contiene Manganeso(II) y la fuerza iónica de esta disolución. El comportamiento de la resina Lewatit K2621 respecto a la eliminación del Manganeso(II) se ha evaluado en presencia de otros elementos metálicos en la disolución acuosa, asimismo se ha comparado el comportamiento de la resina frente a la utilización de otros potenciales adsorbentes para el metal como son los nanotubos de carbono de pared múltiple sin funcionalizar o funcionalizados con grupos carboxílicos. El modelo cinético de pseudoprimer orden explica los resultados cinéticos del proceso de intercambio catiónico, el aumento de temperatura hace que el modelo de cambio iónico responda a dos procesos diferentes, a $20^{\circ} \mathrm{C}$ es del tipo de difusión en el medio acuoso y a $60{ }^{\circ} \mathrm{C}$ el modelo es el de núcleo recesivo. La isoterma de Freundlich se adapta mejor a los resultados obtenidos respecto a la carga del metal en la resina. La elución del Manganeso(II) cargado en la resina se ha investigado mediante el uso de disoluciones acidas $\left(\mathrm{H}_{2} \mathrm{SO}_{4} \mathrm{O} \mathrm{HCl}\right)$.

PALABRAS CLAVE: Efluentes líquidos; Eliminación; Lewatit K2621; Manganeso(II); Nanotubos de carbono de pared múltiple

ORCID ID: Francisco J. Alguacil (https://orcid.org/0000-0002-0247-3384)

Copyright: (C) 2018 CSIC. This is an open-access article distributed under the terms of the Creative Commons Attribution 4.0 International (CC BY 4.0) License. 


\section{INTRODUCTION}

Manganese is a natural occurring element, that as many others metallic elements is essential to human health. In fact, manganese is a normal component of human tissues and fluids, but as can be expected, manganese overexposure can be toxic.

Manganese(II) intake by humans can be done via air, water or food, and health effects of inorganic manganese on humans include: death, systemic, neurologic and developmental (US ATSD, 2012). In the case of waters, and particularly drinking waters, the intake limit established by the World Health Organization is of $400 \mu \mathrm{g} \cdot \mathrm{L}^{-1}$ in a daily basis, whereas concentrations about $0.05 \mathrm{mg} \cdot \mathrm{L}^{-1}$ is normally acceptable for consumption, though the presence of the element in waters can be somewhat objectionable if causes water discoloration, black staining and bitter metallic taste (WHO, 2011; USEPA, 2017). Manganese is non-classified as human carcinogenic (group D). A number of disclosures and future developments on manganese toxicity related to humans can be found elsewhere (O'Neal and Zheng, 2015).

Having manganese(II) these hazardous characteristics, recently, several authors reported about the removal of this ion from aqueous solutions using different types of methodologies (Coskun et al., 2016; Li et al., 2016; Zue et al., 2016; Alexander et al., 2017; Kebabi et al., 2017; Vries et al., 2017).

Next in the series of articles published by the author about the use of ion exchange technology in the removal of toxic metals (Alguacil et al., 2002; Alguacil, 2002; Alguacil, 2003; Alguacil, 2017a; Alguacil, 2017b), the present work reports about the use of the cationic exchange resin Lewatit K2621 on the removal of manganese(II) from aqueous solutions. The experimental results were fitted to models in order to a better understanding of the exchange process.

\section{EXPERIMENTAL}

Lewatit K2621 (Fluka) has the characteristics shown in Table 1. Other chemical used in the investigation were of AR grade, whereas the experimental procedure used here was the same as described in previous works of this series. The multiwalled carbon nanotubes (MWCNTs) presented the next characteristics: carbon content $>98 \%$, outer diameter: $10 \mathrm{~nm} \pm 1 \mathrm{~nm}$, inner diameter: $4.5 \mathrm{~nm} \pm 0.5 \mathrm{~nm}$, length: 3-6 $\mu \mathrm{m}$ ) (Alguacil et al., 2016), whereas the

TABLE 1. Characteristics of Lewatit K2621 resin

\begin{tabular}{ll}
\hline Active group & Sulfonic in $\mathrm{H}^{+}$form \\
Matrix & Crosslinked styrene-DVB \\
Particle form and particle & Spheres, $0.4 \mathrm{~mm}<$ particle \\
size $^{\mathrm{a}}$ & $<1.3 \mathrm{~mm}$ \\
\hline
\end{tabular}

${ }^{a}$ minimum $90 \%$ carboxylic functionalized multiwalled carbon nanotubes (MWCNTs-ox) presented $>8 \%$ carboxylic acid functionalized, $9.5 \mathrm{~nm}$ average diameter and $1.5 \mu \mathrm{m}$ length.

All the loading experiments were carried out in a glass reactor using $200 \mathrm{~mL}$ of the aqueous solution, $1200 \mathrm{rpm}$ and $20{ }^{\circ} \mathrm{C}$, except when these variables were investigated.

Metals in solution were analysed by AAS spectrophotometry, whereas metals load in the resin was calculated by the mass balance.

\section{RESULTS AND DISCUSSION}

\subsection{Manganese uptake onto the resin}

The equilibrium which represented the loading of Manganese(II) onto the resin Lewatit K2621 can be represented by a cationic exchange between protons of the sulfonic group of the resin and $\mathrm{Mn}^{2+}$ from the aqueous solution, thus:

$$
2\left(\mathrm{R}-\mathrm{SO}_{3}^{-} \mathrm{H}^{+}\right)_{\mathrm{r}}+\mathrm{Mn}_{\mathrm{aq}}^{2+} \Leftrightarrow\left(2\left(\mathrm{R}-\mathrm{SO}_{3}^{-}\right) \mathrm{Mn}^{2+}\right)_{\mathrm{r}}+2 \mathrm{H}_{\mathrm{aq}}^{+}
$$

where $\mathrm{R}$ is the non-reactive part of the resin, and $r$ and $a q$ represent to the resin and the aqueous solution, respectively.

To investigate the effect of the stirring speed on metal loading onto the resin, aqueous solutions containing $0.01 \mathrm{~g} \cdot \mathrm{L}^{-1}$ manganese(II) at $\mathrm{pH} 5$ were put into contact with $0.5 \mathrm{~g} \cdot \mathrm{L}^{-1}$ of the resin at $20^{\circ} \mathrm{C}$ and various stirring speeds, ranging from 250 to $1400 \mathrm{rpm}$. The results of this set of experiments being shown in Fig. 1, it can be seen (Fig.1 top) that the percentage of metal loaded onto the resin increased as the stirring speed of the system is increased, however in the 1000-1400 rpm range, and specially in the 1200-1400 rpm, this difference is, if any, negligible. Thus, in the 1200-1400 rpm a maximum in metal loading is achieved and a minimum in the thickness of the aqueous boundary layer is reached. Fig. 1 bottom represented the variation of the fractional approach to equilibrium $(F)$ versus time. $F$ values were calculated accordingly with the next expression:

$$
\mathrm{F}=\frac{[\mathrm{Mn}]_{\mathrm{t}, \mathrm{r}}}{[\mathrm{Mn}]_{\mathrm{e}, \mathrm{r}}}
$$

where $[\mathrm{Mn}]_{\mathrm{t}, \mathrm{r}}$ and $[\mathrm{Mn}]_{\mathrm{e}, \mathrm{r}}$ represented the manganese concentrations in the resin at an elapsed time $t$ and at equilibrium, respectively. When the fractional approach to equilibrium is considered, it can be seen that there is an initial influence of the stirring speed on the $\mathrm{F}$ value, but after $1 \mathrm{~h}$ of reaction, in all cases, near or more than $50 \%$ of the metal loading is achieved, being practically the $\mathrm{F}$ value 
(a)

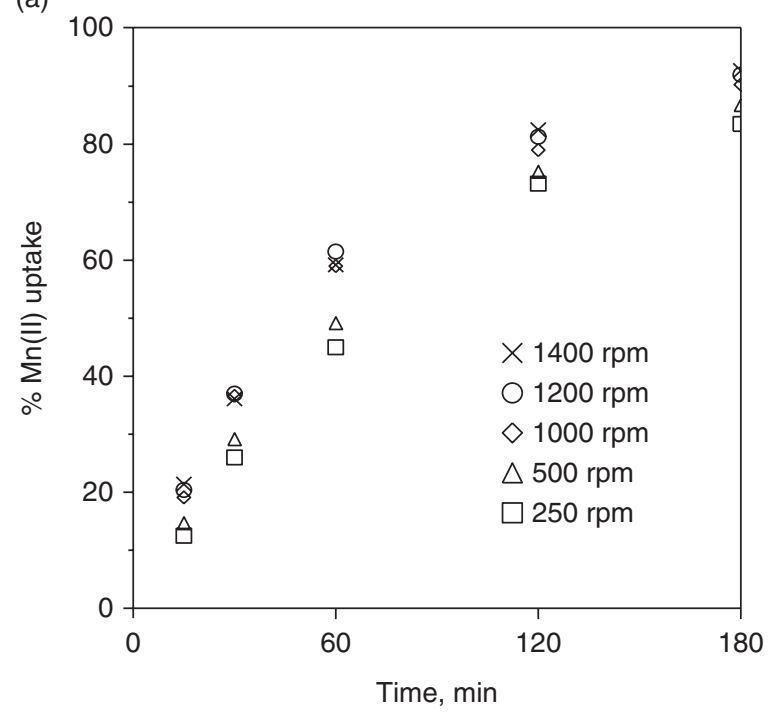

(b)



FIGURE 1. a) Influence of stirring speed on manganese(II) uptake, and b) influence of stirring speed on the factorial approach to equilibrium.

independent of the stirring speed after $2 \mathrm{~h}$ or $3 \mathrm{~h}$ of reaction (near $80 \%$ of $90 \%$ of the total metal loading, respectively), this means that at these times, the rate of metal uptake is independent of the stirring speed, being this independence also evident for stirring speeds greater than $1000 \mathrm{rpm}$ and shorter contact times. Experimental data at $1200 \mathrm{rpm}$ were used to investigate the loading kinetics followed by this system. Thus, data were fit to the pseudo-first or pseudo-second kinetics order models, the results of this fitting showed that the system responded better to the pseudo-first kinetic order model $\left(r^{2}=0.998\right)$ :

$\ln \left([\mathrm{Mn}]_{\mathrm{e}, \mathrm{r}}-[\mathrm{Mn}]_{\mathrm{t}, \mathrm{r}}\right)=\ln [\mathrm{Mn}]_{\mathrm{e}, \mathrm{r}}-\mathrm{kt}$

where $[\mathrm{Mn}]_{\mathrm{er}, \mathrm{r}}$ and $[\mathrm{Mn}]_{\mathrm{t}, \mathrm{r}}$ are the manganese concentrations in the resin at equilibrium and at elapsed time, respectively, $k$ is the rate constant and $t$ the elapsed time. From the numerical data the value of $\mathrm{k}$ was estimated as $0.014 \mathrm{~min}^{-1}$.

Metal loading onto the resin was also investigated as a function of the temperature. In this case, the resin dosage was of $0.25 \mathrm{~g} \cdot \mathrm{L}^{-1}$, whereas the aqueous solution contained $0.01 \mathrm{~g} \cdot \mathrm{L}^{-1} \mathrm{Mn}(\mathrm{II})$ at $\mathrm{pH} 5$. From results showed in Table 2, it can be seen that with the increase of the temperature the metal uptake in the resin increases. In this table, the values of the distribution coefficient D were calculated accordingly with:

$$
\mathrm{D}=\frac{[\mathrm{Mn}(\mathrm{II})]_{\mathrm{e}, \mathrm{r}}}{[\mathrm{Mn}(\mathrm{II})]_{\mathrm{e}, \mathrm{s}}}
$$

TABLE 2. Manganese uptake at various temperatures

\begin{tabular}{lccc}
\hline $\mathbf{T},{ }^{\circ} \mathbf{C}$ & {$[\mathbf{M n}(\mathbf{I I})], \mathbf{m g} \cdot \mathbf{L}^{-\mathbf{1}}$} & {$[\mathbf{M n}(\mathbf{I I})],{\mathbf{~ m g} \cdot \mathbf{g}^{-1}}^{-1}$} & $\log \mathbf{D}^{\mathbf{a}}$ \\
\hline 20 & 1.5 & 34.0 & 1.4 \\
40 & 0.15 & 39.4 & 2.4 \\
60 & 0.01 & 40.0 & 3.6 \\
\hline
\end{tabular}

${ }^{\mathrm{a}}$ Time: $5 \mathrm{~h}$

where $[\mathrm{Mn}(\mathrm{II})]_{\mathrm{e}, \mathrm{r}}$ and $[\mathrm{Mn}(\mathrm{II})]_{\mathrm{e}, \mathrm{s}}$ are the manganese concentrations in the resin and in the solution at equilibrium, respectively. From the experimental values, $\Delta \mathrm{H}^{\circ}$ was calculated as $102.1 \mathrm{~kJ} \cdot \mathrm{mol}^{-1}$, being the exchange reaction endothermic. The values of $\Delta \mathrm{G}^{\circ}$ and $\Delta \mathrm{S}^{\circ}$ calculated for the present system are $-6.5 \mathrm{~kJ} \cdot \mathrm{mol}^{-1}$ (spontaneous system) and $374.2 \mathrm{~J} \cdot \mathrm{K}^{-1} \cdot \mathrm{mol}^{-1}$ (increase of the process randomness), respectively.

Various models were used to investigate the influence of the temperature on the mechanism in which manganese is loaded onto the resin (López DíazPavon et al., 2014). From this fitting, it is showed that at $20^{\circ} \mathrm{C}$, the metal loading onto the resin is better explained by the aqueous diffusion, whereas at $60{ }^{\circ} \mathrm{C}$ the data best fit to the moving boundary model (Table 3).

The variation of the metal loaded onto the resin when the $\mathrm{pH}$ of the solution changes was also considered, and for these experiments solutions containing $0.01 \mathrm{~g} \cdot \mathrm{L}^{-1}$ manganese(II) at $\mathrm{pH}$ values of 5 or 1 , resin concentrations of $0.5 \mathrm{~g} \cdot \mathrm{L}^{-1}$ were used. Fig. 2 showed the variation in the Manganese(II) concentration in the aqueous solution versus time at these $\mathrm{pH}$ values. The $\mathrm{pH}$ of the solution clearly influences the removal of Manganese(II) from the 
TABLE 3. Model fits for manganese uptake at different temperatures

\begin{tabular}{llcl}
\hline $\mathbf{T},{ }^{\circ} \mathbf{C}$ & model & $\mathbf{r}^{2}$ & $\mathbf{k}, \mathbf{m i n}^{-1}$ \\
\hline 20 & $\ln (1-\mathrm{F})=-\mathrm{kt}$ & 0.994 & $9.8 \times 10^{-3}$ \\
60 & $3-3(1-\mathrm{F})^{2 / 3}-2 \mathrm{~F}=\mathrm{kt}$ & 0.993 & $4.9 \times 10^{-3}$ \\
\hline
\end{tabular}

F: calculated as in Eq. (2)

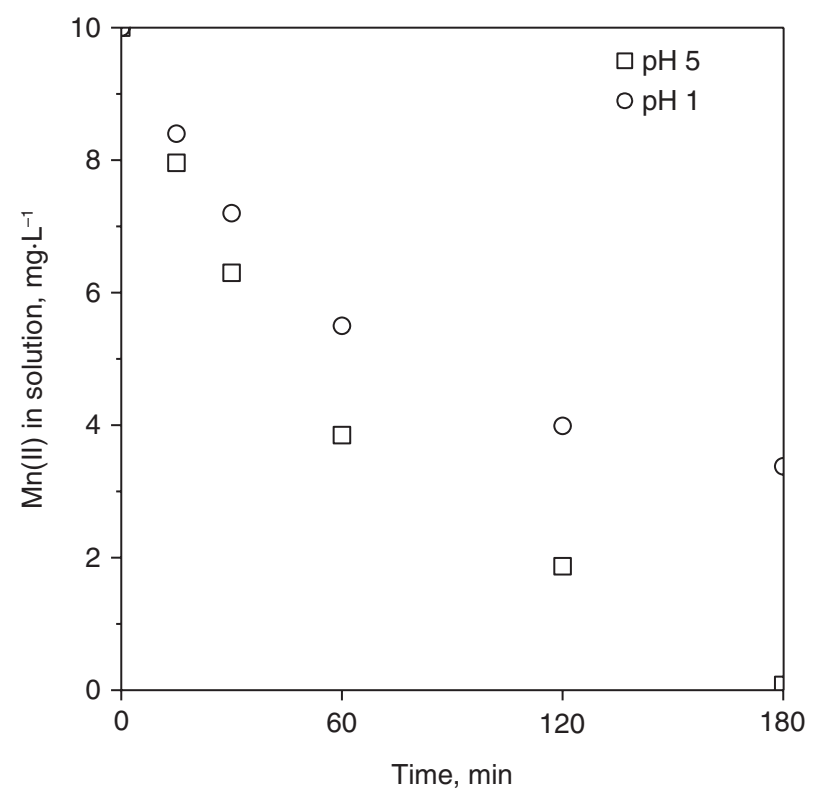

FIGURE 2. Influence of the aqueous $\mathrm{pH}$ on manganese(II) remained in the aqueous solution.

TABLE 4. Influence of the aqueous ionic strength on manganese uptake

\begin{tabular}{|c|c|}
\hline Ionic strength, $M$ & manganese uptake, $\mathrm{mg} \cdot \mathrm{g}^{-1 *}$ \\
\hline 1 & 1.5 \\
\hline 0.5 & 1.9 \\
\hline 0.25 & 6.0 \\
\hline 0.13 & 12.0 \\
\hline $7.2 \times 10^{-4}$ & 34.0 \\
\hline
\end{tabular}

${ }^{*}$ Time: $5 \mathrm{~h}$

solution, increasing the remaining $\mathrm{Mn}(\mathrm{II})$ concentration in the solution as the $\mathrm{pH}$ of the solution becomes more acidic. Metal uptakes at equilibrium are 14.4 and $19.9 \mathrm{mg} \cdot \mathrm{g}^{-1}$ at $\mathrm{pH}$ values of 1 and 5 , respectively, for Manganese(II) concentration in the solution of 2.8 and $0.04 \mathrm{mg} \cdot \mathrm{L}^{-1}$.

The ionic strength of the aqueous solution is another variable which potentially can affect to the exchange reaction and thus the Manganese(II) loads onto the resin. These experiments were carried out with resin doses of $0.25 \mathrm{~g} \cdot \mathrm{L}^{-1}$ and aqueous solutions containing $0.01 \mathrm{~g} \cdot \mathrm{L}^{-1} \mathrm{Mn}(\mathrm{II})$ and various concentrations of $\mathrm{LiCl}$, as the source for the ionic strength variation. Table 4 summarized the results
TABLE 5. Manganese uptake at various resin doses

\begin{tabular}{|c|c|c|}
\hline Resin, $g \cdot \mathrm{L}^{-1}$ & {$[\mathrm{Mn}(\mathrm{II})], \mathbf{m g} \cdot \mathbf{L}^{-1}$} & {$[\mathrm{Mn}(\mathrm{II})], \mathrm{mg} \cdot \mathrm{g}^{-1}$} \\
\hline 0.5 & 0.04 & 19.9 \\
\hline 0.25 & 1.5 & 34.0 \\
\hline 0.13 & 4.5 & 44.0 \\
\hline 0.05 & 6.8 & 64.0 \\
\hline
\end{tabular}

Time: $5 \mathrm{~h}$

from these experiments. It can be seen how clearly the increase of the ionic strength influences the metal uptake, specially when compared with solutions in which no $\mathrm{LiCl}$ are present, thus, with ionic strength almost zero a maximum in metal uptake $\left(34.0 \mathrm{mg} \cdot \mathrm{g}^{-1}\right)$ is reached.

Resin concentrations in the $0.05-0.5 \mathrm{~g} \cdot \mathrm{L}^{-1}$ range were used to investigate the influence of the resin dosage on metal uptake, when aqueous solutions containing $0.01 \mathrm{~g} \cdot \mathrm{L}^{-1} \mathrm{Mn}(\mathrm{II})$ at $\mathrm{pH} 5$ were used as the source for $\mathrm{Mn}^{2+}$ ions. The results of this investigation are summarized in Table 5, as can be expected, the decrease in the resin concentration resulted in an increase of the metal uptake onto the resin, but at the same time, the residual $\mathrm{Mn}^{2+}$ concentration in the solution increases. The experimental data better responded to the Freundlich model $\left(r^{2}=0.901\right)$ :

$$
\ln [\mathrm{Mn}]_{\mathrm{e}, \mathrm{r}}=\ln \mathrm{K}_{\mathrm{F}}+\frac{1}{\mathrm{n}} \ln [\mathrm{Mn}]_{\mathrm{e}, \mathrm{s}}
$$

where $[\mathrm{Mn}]_{e, \mathrm{r}}$ and $[\mathrm{Mn}]_{\mathrm{e}, \mathrm{s}}$ are the manganese concentrations at equilibrium in the resin and in the aqueous solution, respectively, $\mathrm{K}_{\mathrm{F}}$ is a Freundlich constant and $1 / \mathrm{n}$ is a parameter. For the present system $\ln \mathrm{K}_{\mathrm{F}}=3.6$ and $1 / \mathrm{n}=0.199$.

The selectivity of the resin respect to Manganese(II) when other metals are present in the aqueous solution was studied using binary solutions of Manganese(II) and a given metal in equimolar concentrations. Table 6 summarized these results in the form of the experimental separation factors, $\beta_{\mathrm{Mn} / \text { metal }}$ :

$\beta=\frac{\mathrm{D}_{\mathrm{Mn}}}{\mathrm{D}_{\text {Metal }}}$

where D represented the distribution coefficient for the metals, calculated as in Eq. (4). From these results it can be deduced that this resin presented a bad selectivity with respect to manganese(II), since this element only is exchanged favourably in the presence of zinc(II) and indium(III), $\beta>1$, whereas the others metals experimented in this work are exchanged in preference to manganese(II) $(\beta<1)$. The differences in selectivity may be attributed, among others, to: 
TABLE 6. Separation factors $(\beta)$ for various metals-binary solutions using Lewatit K2621 resin as cation exchanger

\begin{tabular}{lc}
\hline System & $\boldsymbol{\beta}_{\mathrm{Mn} / \mathbf{M}}$ \\
\hline $\mathrm{Mn}(\mathrm{II})$ & 0.89 \\
$\mathrm{Cr}(\mathrm{III})$ & \\
$\mathrm{Mn}(\mathrm{II})$ & 0.78 \\
$\mathrm{Co}(\mathrm{II})$ & \\
$\mathrm{Mn}(\mathrm{II})$ & 0.78 \\
$\mathrm{~Pb}(\mathrm{II})$ & \\
$\mathrm{Mn}(\mathrm{II})$ & 0.65 \\
$\mathrm{Ni}(\mathrm{II})$ & \\
$\mathrm{Mn}(\mathrm{II})$ & 0.57 \\
$\mathrm{Cu}(\mathrm{II})$ & \\
$\mathrm{Mn}(\mathrm{II})$ & 1.2 \\
$\mathrm{In}(\mathrm{III})$ & \\
$\mathrm{Mn}(\mathrm{II})$ & 2.3 \\
$\mathrm{Zn}(\mathrm{II})$ &
\end{tabular}

Aqueous solution: $0.17 \mathrm{mmol} \cdot \mathrm{L}^{-1}$ each metal at $\mathrm{pH} 5$; Resin dosage: $0.25 \mathrm{~g} \cdot \mathrm{L}^{-1}$

Temperature: $20^{\circ} \mathrm{C}$; Time: $7 \mathrm{~h}$

TABLE 7. Metal uptake obtained with different types of exchanger-adsorbents

\begin{tabular}{lc}
\hline Exchanger-adsorbent & Mn(II) uptake, $\mathbf{~ m g} \cdot \mathbf{g}^{-1}$ \\
\hline Lewatit K2621 & 19.9 \\
MWCNTs & 2.5 \\
MWCNTs-ox & 8.0 \\
\hline
\end{tabular}

Aqueous solution: $0.01 \mathrm{~g} \cdot \mathrm{L}^{-1} \mathrm{Mn}(\mathrm{II})$ at $\mathrm{pH}$ 5; Resin or carbon nanotubes dosage: $0.5 \mathrm{~g} \cdot \mathrm{L}^{-1}$;

Temperature: $20^{\circ} \mathrm{C}$; Time: $5 \mathrm{~h}$

i) The easiness (affinity) in which the cation is exchanged with the proton from the resin, resulting in greater metal uptake.

ii) The different rate of the metal loading onto the resin.

Also the exchange capacities of the resin with respect to other smart metal-adsorbents or exchangers, as functionalized and non-functionalized multiwalled carbon nanotubes are examined. The results of this investigation are shown in Table 7, it can be seen that the results obtained within the resin are far better than those obtained with the two types of multiwalled carbon nanotubes.

\subsection{Metal elution from the loaded resin}

Hydrochloric acid and sulfuric acid were used as eluents for the present system. The elution step in this system can be related to an exchange of the manganese ions loaded onto the resin with the correspondent concentration of protons released from the acids, that is a shifting of Eq. (1) to the left.

The use of both acids results in an acceptable yield in the recovery of manganese, $85.0 \%$ and $92.3 \%$ for sulfuric and hydrochloric acid, respectively.

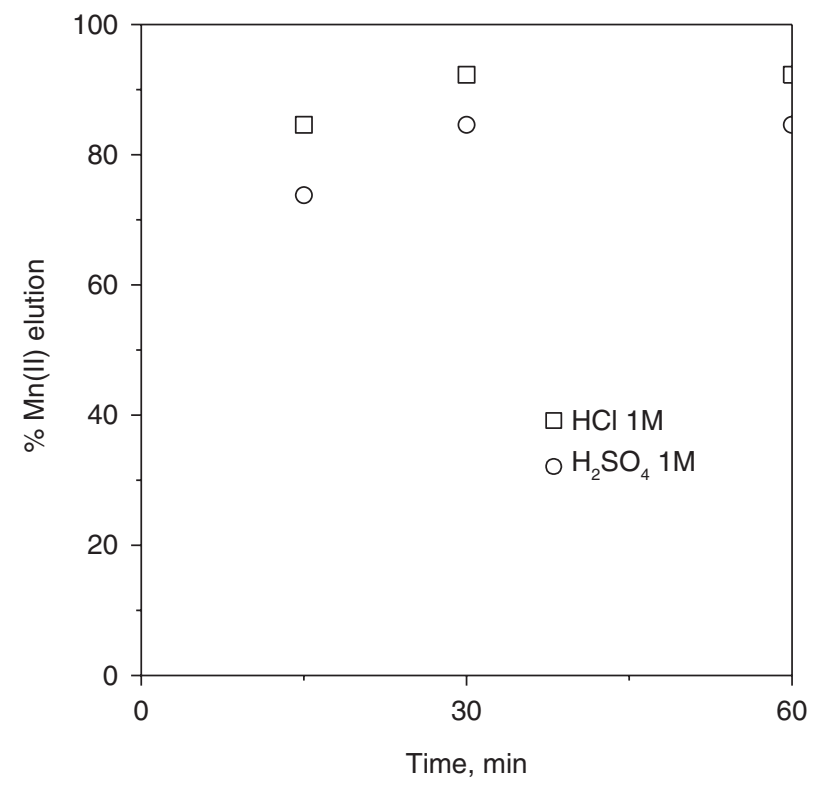

FigURE 3. Influence of the acid on manganese(II) elution from $\mathrm{Mn}(\mathrm{II})$-loaded resin.

TABLE 8. Elution of $\mathrm{Mn}(\mathrm{II})$ using $\mathrm{H}_{2} \mathrm{SO}_{4}$ solution as eluent

\begin{tabular}{lcc}
\hline Liquid/resin ratio, $\mathbf{~} \mathbf{L} \cdot \mathbf{g}^{\mathbf{- 1}}$ & \% elution & $\mathbf{[ M n}(\mathbf{I I})], \mathbf{g} \cdot \mathbf{L}^{\mathbf{- 1}}$ \\
\hline 250 & 85.0 & 0.06 \\
\hline 125 & 84.6 & 0.11 \\
\hline
\end{tabular}

Aqueous solution: $\mathrm{H}_{2} \mathrm{SO}_{4} 1 \mathrm{M}$; Resin: $0.1 \mathrm{~g}$; loaded with $1.6 \mathrm{mg}$ Mn(II); Time: $1 \mathrm{~h}$; Temperature: $20^{\circ} \mathrm{C}$

Reaching the equilibrium, also in both cases, within 30 min of contact between the $\mathrm{Mn}$ (II)-loaded resin and the respective elution solution (Fig. 3). The conditions for the above experiments were: $0.1 \mathrm{~g}$ resin loaded with $1.6 \mathrm{mg} \mathrm{Mn(II),} \mathrm{aqueous} \mathrm{solution:} \mathrm{the}$ corresponding acid, liquid/resin ratio: $125 / 1 \mathrm{~mL} \cdot \mathrm{g}^{-1}$, temperature: $20^{\circ} \mathrm{C}$, time: 15,30 and $60 \mathrm{~min}$. The effect of varying the solution/resin ration was also investigated in the case of $\mathrm{H}_{2} \mathrm{SO}_{4}$ in order to evaluate if this variation has any effect on the percentage of Manganese(II) elution. The results from these tests are shown in Table 8, and it can be seen that this variation has not any influence in the recovery of the metal from the loaded resin. In any case it can be observed that near a ten-fold increase in the concentration of Manganese(II) in the solution, with respect to the initial one, can be achieved using the proper liquid volume/resin weight ratio.

\section{CONCLUSIONS}

- The resin Lewatit K2621 can be used in the removal of manganese(II) from solutions of $\mathrm{pH}$ 5 or near this value, the decrease of the aqueous $\mathrm{pH}$ dramatically hampered the use of this resin in the removal of this element. Also the increase 
of the aqueous ionic strength and the decrease of the temperature (the exchange reaction being endothermic) are detrimental for the manganese uptake onto the resin.

- The variation of the temperature also produced a change in the adsorption model, at $20^{\circ} \mathrm{C}$, the aqueous diffusion model best explained the experimental results (rate constant estimated as $9.8 \times 10^{-3} \mathrm{~min}^{-1}$ ), whereas at $60{ }^{\circ} \mathrm{C}$ the metal loading process is best explained by the moving boundary model (rate constant $4.9 \times 10^{-3} \mathrm{~min}^{-1}$ ).

- The loading of the metal can be related to the Freundlich equation and the pseudo-first kinetic order equation (rate constant estimated as $0.014 \mathrm{~min}^{-1}$ ).

- The Lewatit K2621 resin is only selective with respect to manganese when zinc(II) or indium(III) are presented in the aqueous solution, in the presence of $\mathrm{Cr}$ (III), $\mathrm{Co}(\mathrm{II}), \mathrm{Pb}$ (II), $\mathrm{Ni}(\mathrm{II})$ and $\mathrm{Cu}(\mathrm{II})$, the above elements are loaded onto the resin preferably to manganese(II). This resin presented better removal characteristics (greater metal uptake) with respect to manganese(II) than those presented by the carboxylic-functionalized or non-functionalized multiwalled carbon nanotubes tested in this work. Manganese(II) can be recovered from the loaded resin by the use of mineral acids, such as $\mathrm{HCl}$ or $\mathrm{H}_{2} \mathrm{SO}_{4}$, solutions, the recovery is fast (30 $\mathrm{min}$ ) and the yield is around $90 \%$ for both acids, ten-fold increasing concentration, with respect to the initial manganese(II) concentration, can be reached, i.e.: $0.11 \mathrm{~g} \cdot \mathrm{L}^{-1}$ against the initial $0.01 \mathrm{~g} \cdot \mathrm{L}^{-1}$.

\section{ACKNOWLEDGEMENT}

To the CSIC (Spain) for support. To Mr. J.M. Medina for assistance in part of the experimental work.

\section{REFERENCES}

Alexander, J.A., Ahmad Zaini, M.A., Surajudeen, A., Aliyu, E.-N.U., Omeiza, A.U. (2017). Insight into kinetics and thermodynamics properties of multicomponent lead(II), cadmium(II) and manganese(II) adsorption onto DijahMonkin bentonite clay. Particul. Sci. Technol. (In press), 1-9. https://doi.org/10.1080/02726351.2016.1276499.

Alguacil, F.J., Coedo, A.G., Dorado, T., Padilla, I. (2002). The removal of toxic metals from liquid effluents by ion exchange resins. Part I: chromium(VI)/sulphate/Dowex 1×8. Rev. Metal. 38 (4), 306-311. https://doi.org/10.3989/ revmetalm.2002.v38.i4.

Alguacil, F.J. (2002). The removal of toxic metals from liquid effluents by ion exchange resins. Part II: cadmium(II)/sulphate/ Lewatit TP260. Rev. Metal. 38 (5), 348-352. https://doi.org/ 10.3989/revmetalm.2002.v38.i5.

Alguacil, F.J. (2003). The removal of toxic metals from liquid effluents by ion exchange resins. Part III: copper(II)/sulphate/Amberlite 200. Rev. Metal. 39 (3), 205-209. https:// doi.org/10.3989/revmetalm.2003.v39.i3.

Alguacil, F.J. (2017a). The removal of toxic metals from liquid effluents by ion exchange resins. Part IV: chromium(III)/ H+/Lewatit SP112. Rev. Metal. 53 (2), e093. https://doi. org/10.3989/revmetalm.093.

Alguacil, FJ (2017b). The removal of toxic metals from liquid effluents by ion exchange resins. Part V: Nickel(II)/H+/ Dowex C400. Rev. Metal. 53 (4), e105. https://doi.org/ 10.3989/revmetalm.105.

Alguacil, F.J., López, F.A., Rodriguez, O., Martinez-Ramirez, S., García-Díaz, I. (2016). Sorption of indium (III) onto carbon nanotubes. Ecotox. Environ. Safe. 130, 81-86. https:// doi.org/10.1016/j.ecoenv.2016.04.008.

Coşkun, G., Şimşek, I., Arar, A., Yüksel, A., Yüksel, M. (2016). Comparison of chelating ligands on manganese(II) removal from aqueous solutions. Desalin. Water Treat. 57 (3), 25739 25746. https://doi.org/10.1080/19443994.2016.1153984.

Kebabi, B., Terchi, S., Bougherara, H., Reinert, L., Duclaux, L. (2017). Removal of manganese (II) by edge site adsorption on raw and milled vermiculites. Appl. Clay Sci. 139, 92-98. https://doi.org/10.1016/j.clay.2016.12.041.

Li, N., Zhao, J., Jiang, Z., Cao, B., Lu, Y., Shan, D. (2016). Continuous manganese(II) ions removal from aqueous solutions using rice husk ash-packed column reactor. Desalin. Water Treat. 57 (46), 21916-21924. https://doi.org/10.1080 /19443994.2015.1128362.

López Díaz-Pavón, A., Cerpa, A., Alguacil, F.J. (2014). Processing of indium(III) solutions via ion exchange with Lewatit K-2621 resin. Rev. Metal. 50 (2), e010. https://doi. org/10.3989/revmetalm.010.

O'Neal, S.L., Zheng, W. (2015). Manganese toxicity upon overexposure: A decade in review. Curr. Environ. Health Rpt. 2 (3), 315-328. https://doi.org/10.1007/s40572-015-0056-x.

US ATSDR (2012). Toxicological Profile for Manganese. Agency for Toxic Substances and Disease Registry (ATSDR), Atlanta, Giorgia. https://www.atsdr.cdc.gov/toxprofiles/ tp151.pdf.

USEPA (2017). Report: Secondary drinking water standards: guidance for nuisance chemicals. United States Environmental Protection Agency https://www.epa.gov/ dwstandardsregulations/secondary-drinking-water-standards-guidance-nuisance-chemicals.

Vries, D., Bertelkamp, C., Schoonenberg Kegel, F., Hofs, B., Dusseldorp, J., Bruins J.H., de Vet, W., Van den Akker, B. (2017). Iron and manganese removal: Recent advances in modelling treatment efficiency by rapid sand filtration. Water Res. 109, 35-45. https://doi.org/10.1016/j. watres. 2016.11.032.

WHO (2011). Manganese in drinking-water. World Health Organization, Guidelines for Drinking-water Quality. https:// www.who.int/water_sanitation_health/dwq/chemicals/ manganese.pdf.

Zue, M., Makani, T., Eba, F. (2016). Removal of Mn(II) from aqueous solutions by activated carbon prepared from Coula edulis nut shell. J. Environ. Sci. Technol. 9 (2), 226-237. https://doi.org/10.3923/jest.2016.226.237. 